\title{
The Role of Bumiputera Young Limited Company in The Doctor Professional Insurance Claim Process for Medical Dispute Settlement
}

\author{
Reinhard John Devison ${ }^{1}$, Kartina Pakpahan ${ }^{2}$, July Esther ${ }^{3}$, Herlina Manullang ${ }^{4}$ \\ \{reinhardhutahaean@gmail.com ${ }^{1}$ kartinapakpahan@unprimdn.ac.id ${ }^{2}$, julyesther@uhn.ac.id ${ }^{3}$, \\ herlinamanullang@uhn.ac.id $\left.{ }^{4}\right\}$ \\ Universitas Prima Indonesia ${ }^{12}$ \\ Universitas HKBP Nommensen Medan ${ }^{34}$
}

\begin{abstract}
In carrying out his noble profession, doctors will certainly always provide the best service to patients. However, in practice, it is undeniable that sometimes medical disputes occur between doctors or hospitals where doctors practice with patients and their families. In resolving medical disputes that occur, it refers to Law Number 36 of 2009 concerning Health, which in article 29 states that if health workers are suspected of negligence in carrying out their profession, the negligence must be resolved first through mediation. The participation of a doctor in an insurance product is a transfer of burden from the doctor (the insured) by the insurance party (the insurer). On the other hand, doctors who are participants in the medical professional insurance product issued by the Bumi Putera Muda Professional Insurance Limited Company have the right to claim for the claims of patients/patients' families in medical disputes that occur and their resolution through mediation process that requires the provision of affection funds from doctor to patient/patient family. The nature of this research is descriptive-analytical, meaning that this research aims to describe (describe) systematically and factually to get the facts and what should be done to solve the problems that occur, and by using normative juridical research methods where research refers to the research literature by examining library materials and interviews, this research will show how the role of the Bumi Putera Muda Professional Insurance Limited Company in the mediation process for the resolution of medical disputes that occur, namely by providing peace funds (charity funds) which are transferred to a third party, namely the insurance as the insurer through the claim process by the doctor as the insured.
\end{abstract}

Keywords: Insurance, Claim Process, Medical Dispute

\section{Introduction}

Health is one of the significant elements that must be fulfilled in human life. Fulfilling the health need is the key that is most prioritized by humans in addition to other needs. The fulfillment of the health needs of every human being has become a state affair in ensuring the health of every citizen, as stated in Article 28H Paragraph (1) of the 1945 Constitution of the Republic of Indonesia (UUD NRI 1945) that reads: " everyone has the right to live physically and mentally prosperous, have a place to live, and get a good and healthy living environment and have the right to obtain health services. 
Health insurance is also further regulated through Law Number 44 of 2009 concerning Hospitals, Law Number 29 of 2004 concerning Medical Practice, and Law Number 36 of 2009 concerning Health which regulates patient rights. The regulations governing patients as consumers of health services are regulated by Law Number 8 of 1999 concerning Consumer Protection.

The medical profession is a noble profession, which has the basic essence of saving human life based on nobility and nobility shown through the characteristics of upholding the nature of divinity, the existence of purity of intention, nobility of mind, providing service to patients with humility. , seriousness in doing work, and the presence of scientific and social integrity. The noble values of the medical profession contained in a medical service guideline which then distinguishes between the medical profession and professions in other fields of expertise.

The relationship that occurs between the patient and the doctor is divided into two, namely: "The relationship because of therapeutic actions and the relationship because of the law," Basically, according to the law, the services provided by doctors to patients are in the form of services that are therapeutic transactions or known as various verbs, namely engagements that arise with caution and require considerable effort. Therefore, if things happen that are not appropriate or lead to failure of treatment by a doctor, the risk must be borne by both parties that can then give rise to medical disputes.

In general, this medical dispute case only occurs if there is a complaint submitted to the patient or a complaint to the police, or a lawsuit against the local district court. Therefore, in a medical dispute, this is a complaint offense. In general, every human action or deed will not run smoothly and get success. Sometimes there will also be risks and losses. This loss is often a sight for everyone, so they frequently don't feel safe if they have to suffer losses alone. Therefore, what is often taken is to make a loss for the disadvantages to another party by having previously made a risk transfer agreement, this agreement is the one that is responsible for insurance.

The explanation of insurance implies an understanding that there is a risk that will occur, but the risk cannot be ascertained. Before the risk occurs, the insured party, in this case, the doctor, has decided the risk to the insurer (insurance) by paying a predetermined premium not sure of that. The more advanced the times, the awareness of every human being will be higher as well.

In Indonesia itself, there are various kinds of products from insurance institutions, and one of the existing products is insurance from doctors issued by the Bumi Putra Muda Limited Company (LC. BUMIDA), where this product is helpful for the medical profession because doctors in carrying out their profession cannot be separated from A problem that can arise as a result of a claim from the patient is called a medical dispute. If the doctor as the insured experiences a medical dispute in the form of his patient, the insured party can make a claim against the insurance company as the insurer. For every claim that claims, the doctor must comply with the procedure for submitting a claim and fulfill the requirements for submitting a claim set by LC. BUMIDA (Bumi Putera Muda).

In the medical profession insurance LC. BUMIDA, can be claimed by a doctor without a court decision that has permanent legal force. However, the claim can only be submitted after the case experienced by the doctor is assessed by the Medico legal Team of LC. BUMIDA. Through an assessment by the Medico legal Team of LC. BUMIDA, an agreement between the doctor and patient to the mediation process that has been agreed by both parties, then LC. BUMIDA can pay the funds/costs of peace without having to wait for a court decision. Through these peace funds/costs, the completion of the medical dispute case faced by the 
doctor will automatically be as a whole, overall, what is meant here is a medical dispute that may have both criminal (disciplinary), civil, and administrative elements by a peace agreement made in between the parties will resolve all forms of existing medical disputes.

The existing regulations at LC. BUMIDA has set the premise that must be determined according to the category of the doctor's profession (specialist) that is owned, namely that the medical professional insurance product issued by LC. BUMIDA is set to have 3 premium levels in a year, namely a premium of IDR. 2,000,000 for doctors. General and the like, the premium is IDR. 5,500,000 for certain specialists and IDR. 7,500,000 for certain other specialists, where the maximum claimed for the entire premium level is a maximum of IDR. $500,000,000$.

However, the complicated problem is related to the number of claim payments that will be made by LC. BUMIDA through the assessment of the Medico legal Team, where there is no standard formula to determine the number of claims for each case faced (other than the maximum claim). Therefore, based on the description of the author's background above is interested in conducting research entitled "Earth Putera Muda Limited Company in the Process of Medical Professional Insurance for Medical Dispute Resolution”.

Determination the formulations of the problem in this study are:

1. Does the medical professional insurance policy issued by BUMIDA Limited Company comply with the principles and as agreed?

2. The process of claiming the BUMIDA Limited medical professional insurance policy in resolving medical disputes?

3. What are the obstacles for BUMIDA Limited Company in making medical professional insurance claims?

\section{Results and Discussion}

\subsection{Medical Dispute}

Medical Disputes are "disputes that occur between patients or their families and health workers or between patients and hospitals/health facilities. Usually disputed is the result or result of health services by not paying attention to or ignoring the process. Then the explanation of medical disputes in positive law is defined as disputes that occur because of the interests of patients harmed by the actions of doctors or dentists who practice medicine. When there is a medical dispute, actually there are various problems that can underlie medical disputes including criminal, civil, scientific disciplines, ethics, and administration. Civil law, MKDKI (Honorary Council for Indonesian Medical Discipline), and MKEK (Honorary Council for Medical Ethics).

Laura Nader and Harry F. Todd Jr for legal anthropologists suggest that there are seven ways of resolving disputes, namely:

1. Lumping it (allowing), namely the party who feels the injustice fails to make demands for his rights so that he decides to let it go.

2. Avoidance, meaning that the party experiencing the loss avoids a relationship that involves re-engagement between him and the party that harms.

3. Coercion (coercion), meaning that one party imposes his will to resolve the dispute that occurs and is usually accompanied by acts of violence so that peaceful efforts will be hard to achieve. 
4. Negotiation (negotiation), which is an effort to resolve disputes carried out by both parties without the involvement of other parties, and the parties have agreed to complete them based on the rules they have made and agreed on.

5. Mediation is a method of dispute resolution involving a neutral third party. Where the third party is chosen by both parties themselves or appointed by an authorized party such as a court, if a decision has been obtained as a result of the mediation, the parties must respect and implement the result of the decision.

6. Arbitration, namely in this point disputing parties have agreed to use the services of a third party, namely the arbitrator, and will comply with any decisions made by the arbitrator.

7. Adjudication (judicial), namely; a third party has the authority to intervene in resolving the problems faced by the parties regardless of the wishes of the parties, and if a settlement in this dispute has been obtained, the parties must comply with any existing decisions.

The seven ways of resolving disputes can be classified into three major parts, namely; traditional settlement, alternative dispute resolution, and court settlement. If it is related to the process of resolving medical disputes that are often faced by doctors and patients as parties, this settlement can be classified into settlement through negotiation and/or mediation which then if there is no agreement. It will proceed with the arbitration and if no agreement is reached between the parties. Each party will then proceed to the settlement through the courts.

\subsection{Definition of insurance}

The word insurance comes from the Dutch language called Verzekering that means coverage, then the insurer is called assuraduer, and the insured is called geassuradeur. Regulations regarding insurance are not only regulated in the Civil Code but are also regulated in the Commercial Code, and Law Number 40 of 2014 concerning Insurance. However, the regulation regarding that insurance is more regulated in the Comrcial Law and even Law Number 40 of 2014 concerning Insurance. In the Civil Code, this insurance is only regulated in Article 1774 of the Civil Code which reads: "a chancy agreement is an act which results in profit and loss, both for all parties and for some parties, depending on an uncertain event".

In the past, insurance started with a social gathering formed by a group of people to ease the burden on individuals who suffered losses so that the losses they bore were not too heavy if borne together. In the Commercial Code (KUHD), insurance is regulated in the First Book Chapter IX Article 246 KUHD that reads: "An agreement of an insurer who finds himself to an insured, with a premium, to provide compensation to him for a loss, damage, or loss of expected profits, which he may suffer due to an unspecified event".

Meanwhile, according to Article 1 point 1 of Law Number 2 of 1992 concerning Insurance Business, it is inteIDRreted that, "an agreement between two insurers binds themselves to the insured by receiving insurance premiums, to provide compensation to the insured due to loss, damage, or loss of expected profits or losses. legal liability to third parties that may be suffered by the insured, arising from an uncertain event, or to provide a payment based on the death or life of the insured person. Furthermore, the latest regulation regarding insurance is also regulated again in Law Number 40 of 2014 concerning Insurance in Article 1 Number (1), which states that: Insurance is an agreement between two parties, namely the insurance company and the policyholder, who become the basis for receipt of premiums by insurance companies in return for: 
a. provide compensation to the insured or policyholder due to loss, damage, costs incurred, loss of profit, or legal liability to third parties that may suffer by the insured or policyholder due to the occurrence of an uncertain event; or

b. provide payments based on the death of the insured, or payments based on the life of the insured with benefits whose amount has been determined and based on the results of fund management.

There are many definitions of insurance according to several experts, one of that is according to Wirdjono Prodjodikoro, states that insurance is; "an agreement in that the guaranteeing party promises to the guaranteed party, to receive a certain amount of premium money as compensation for losses, that may suffer by the guaranteed party". Because the result of an event is not yet clear. Meanwhile, according to Tuti Rastuti, insurance is; "A form of risk management or risk control, by transferring risk (transfer of risk) or sharing risk (distribution of risk) from parties who have the possibility of suffering due to risk to other parties (insurance companies). Who are willing to protect against possible risks to the first party." So simply referring to the opinion of several experts, it can be concluded that insurance is a mechanism that can protect the insured party if they experience a loss in the future.

The elements contained in the definition of insurance are the insured loss, the amount of premium to be paid, and the amount of money that will pay for the loss. The amount of each that must be paid varies according to the level of loss to be insured. Referring to article 246 of the KUHD and also Article 1 of Law No. 40 of 2014 concerning Insurance, it states that insurance contains 3 elements, namely the insured party is the party who must pay money to the insurer, the insurer is the party who is obliged to bear the insured party by paying money to the insurer if the third element is fulfilled, and the incident is not yet clear.

As for the types of coverage in article 247 of the KUHD including mentioning the danger of fire, the danger that threatens agricultural products that have not been harvested, the life of one or more people, the danger of the sea, and the danger of slavery, and the danger of transportation $\mathrm{n}$ on land, rivers, and inland waters. Based on the article above, the new types of insurance are not limited to this. Emmy Pangaribuan Simanjuntak's opinion states that the coverage can adjust to the needs of the community as the word "among others", is the key implied in article 247 of the KUHD and is also based on Article 1338 paragraph (1) of the Civil Code, which subsequently became the basis for the issuance of LC. BUMIDA's insurance product in the form of professional liability insurance.

When talking about medical professional liability insurance, it means discussing the transfer of risks caused by medical actions taken by doctors in dealing with patients. 2011 Regarding the Organization of Medical Committees in Hospitals in Chapter III number 12point $\mathrm{D}$ which states that doctors who work in hospitals are "Doctors have professional protection insurance (Professional Indemnity Insurance)". This professional insurance serves to protect every doctor when dealing with the law to transfer the liability carried out by the patient to a third party.

\subsection{Principles and Principles of Legal Insurance Policy}

Insurance is a special agreement that has been stipulated in the KUHD so that in addition to adhering to general principles, insurance must also contain other special principles.

There are several kinds of principles that must meet in insurance, namely:

a. Insurable Interest (Insurable Interest)

b. Utmost good faith

c. A cause that can cause an event (proximate cause)

d. The principle of balance (Indemniteit Principle) 
e. The principle of subrogation

f. Distribution of other insurers in responsibility (Contribution)

The characteristics that limit the insurer in insurance are as follows:

a. Insurance agreement is a compensation agreement, where the insurer binds the insured party by paying the agreed premium

b. Insurance is a conditional agreement, meaning that this insurance can only be implemented if the unwanted event does occur

c. Insurance is a reciprocal agreement, meaning that each party has their respective obligations, namely paying premiums for the insured and bearing compensation for the insurer.

d. The loss that is the object of insurance is uncertain.

Regarding the legal terms of the insurance agreement, it still refers to the legal terms of an agreement that has been stipulated by the Civil Code that is regulated in article 1320 because the KUHD does not regulate the legal terms of an agreement The following are the legal terms of the insurance agreement as stipulated in Article 1320 of the Civil Code, which are as follows:

a. Agreement, in the insurance agreement both parties who will bind themselves must mutually have an agreement so that the engagement can occur. In the case of insurance, the offer is made by the insured party, while the insurer is the party who accepts the agreement. The agreement made by both parties adheres to the principle of utmost good faith, which is not only carried out by the insured party who must speak honestly but must follow by both parties.

b. Talking, namely the parties who will agree must be competent people in the sense of being mature, sane, and not under guardianship.

c. A certain thing, in this case, is meant by a certain thing is the object that is the basis of the agreement where the object of the agreement is the insurance so that between the insured and the object of the agreement must have a direct relationship.

d. Because the lawful object (legal object) refers to article 1337 of the Civil Code, where if in this case the insurance is contrary to the article, the agreement will be null and void.

e. Legal form, means that the insurance has a legal establish if the insurance policy is following the authorized insurance policy.

\subsection{Bumiputera Muda Limited Company Insurance (LC.BUMIDA)}

Discussing LC Insurance Bumi Putra Muda, of course, it cannot be separated from the management of the Joint Life Insurance of Bumiputera 1912. In the Big Indonesian Dictionary, Bumi Putera comes from the Malay language means, "Son of the earth", or "Child of the land". Bumi Putra insurance was established after the birth of Boedi Oetomo, was founded in Magelang on February 12, 1912, under the name Onderlinge Levenserzekering Maatschappij, the George Association of the Netherlands East Indies or abbreviated as O.L. Mij, PGHB. Besides Mas Ngabehi Dewidjo Sajewo, several other people took part in establishing Bumi Putra such as MKH Soebroto who later served as director, and M. Aimidjojo as treasurer of this Bumi Putra Company and for the first-time policyholders were R. Soepadmo and M. Darno Midjojo.

The journey of the son's earth insurance, which began in Magelang, has moved offices several times, wherein 1921 it was based in Yogyakarta and then finally moved to Jakarta in 1958 until now its head office is in Jakarta. Notary Raden Soerojo Wongsowidjojo, SH ratified the establishment of Bumi Putera Muda Insurance (BUMIDA) according to Notary 
deed No. 7 dated December 8, 1967, domiciled in Jakarta and permitted to carry out operational activities through letter No. KEEP. 350/DJM/111.3/7/1973 dated July 24, 1973, which was later extended in 1986. As for LC Asuransi Umum Bumiputera Muda 1967, the Sharia Unit (BUMIDA Syariah) was officially operating since April 1, 2004, based on a Permit from the Minister of Finance of the Republic of Indonesia number: Kep075/KM.6/2004 dated February 19, 2004.

BUMIDA Insurance has operated its company with "Owned Capital of IDR.256.67 billion, and this shows that BUMIDA has complied with the regulations contained in POJK No.71/POJK.05/2016 article 33 requires every insurance company to have its capital of at least IDR. .100 M. As the oldest insurance company, Bumi Putra still adheres to the principle of cooperation and mutual interest which is different from other insurances and is increasingly expanding its wings with various insurance products offered by BUMIDA, namely: health insurance, transportation insurance, insurance vehicles, money insurance, fire insurance, personal accident insurance, surety bonds, customs bonds, construction work insurance, erection all risk insurance, and engine damage insurance, and of course also doctor's liability insurance.

For Sharia insurance products that are currently still used and have a lot of interest, doctors' professional insurance is one of the insurances that is recommended to be owned by every doctor as a form of transfer of responsibility if one day there is a risk to the profession. This liability insurance product for the medical profession has received a marketing permit from the minister of finance through number S.3880/LK/2004 dated September 3, 2004, so that this professional insurance can be marketed to doctors throughout Indonesia while keeping in mind the Decree of the Minister of Finance Number 422/KMK. 06/2003 in article 7 , every insurance coverage must be guided following the insurance policy specimen reported to the Minister.

\subsection{LC. BUMIDA's doctor's liability insurance policies, premiums and coverage}

According to Article 1 number 6 of the Regulation of the Financial Services Authority Number 23/Pojk.05/2015 concerning Insurance Products and Marketing of Insurance Products. It states that an insurance policy is, "insurance agreement deed or another document that is equivalent to an insurance agreement deed, as well as other documents which are an integral part of the insurance policy. That is inseparable from the insurance agreement, which is made in writing and contains an agreement between the insurance company and the policyholder.

Furthermore, Article 19 Paragraph (1) of Government Regulation Number 73 of 1992 concerning Insurance Business Operators which states that: "A policy or form of insurance agreement with any name, the form of attachment which is an integral part of it, may not contain words or sentences can lead to different interpretations of the risks covered by the insurance, the obligations of the insurer, the obligations of the insured, or make it difficult for the insured to manage his rights".

So, the policy is a very important thing in the insurance world because the policy functions as written evidence that proves that an agreement has occurred between the insured and the insurer. Thus, all things contained in the policy must be clear so that there are no various interpretations that will make it difficult for both parties to carry out their rights and obligations.

An insurance policy has five important elements, which are as follows:

1. The parties are the insurer and the insured;

2. Risk transfer, concerning what risk will be transferred to the insured party; 
3. Premiums;

4. Unspecified events;

5. Compensation.

For the form and content of the medical professional insurance policy issued by

BUMIDA, it contains several parts, such as

1. Scope of coverage which consists of the insurance agreement, payment of insurance claims, and exclusions,

2. Insured,

3. Insurance limitation,

4. Requirements consisting of dispute resolution, cancellation, medico-legal assistance and claim settlement, the insured's liability in the event of a claim or claim, inspection, notification, policy insurance, policy modification, premium and premium adjustment, reactivation of the canceled policy due to late payment of premiums, automatic renewal, changes in risk, requirements, transfer of reacquisition rights to other parties to the insurer, transfer of rights and obligations of the insured party in this policy,

5. The extension of the reporting period consists of the insurer will automatically provide an extension of the reporting period, the extension of the Reporting period is provided without additional premiums, the Extension of the Reporting Period is not intended to restate or increase the Insurance Limit applicable to existing claims,

6. Definition consisting of bodily injury, claim, cost of the claim, incident or event, negligence of medical action, profession of the insured, doctor/dentist, specialist doctor or dentist specialist, patient, the amount that is the responsibility of the insured, insurance period, policy year, and loss of property.

The insurance agreement contained in the BUMIDA product doctor professional insurance policy contains insurance made between the insurer and the insured with a certain amount of compensation provided that the policy is still valid when the incident takes place. Then this insurance also applies to health workers who jointly assist the insured in This insurance only applies if the loss arises and there is a claim from the patient that is made orally or in writing and only applies to compensation for losses located in the country of the address of the insured party. Furthermore, this compensation can only be paid if following the provisions of this insurance.

Payment of insurance claims stipulated in the BUMIDA doctor's professional insurance policy includes the cost of compensation claims and legal fees for claim settlement, a maximum of the sum insured stated in the policy summary, which is IDR. 500,000,000. For the exception section, it discusses the burden of compensation that is not the responsibility of the insurer, which is as follows:

a. All claims arising from events that occurred before the date of this policy period, unless the event occurred during the previous policy period.

b. Loss which is expected or desired or planned by the Insured.

c. Losses due to war, invasion, acts of foreign enemies, clashes, civil wars, riots, rebellions, terrorism, revolutions, military force or seizure of power, riots, strikes, bans from work, military insurrections, civilian deployments, seizure of material, robbery and looting, confiscation or destruction by governmental or public authorities, or acts or circumstances such as any of the above, whether the state is declared war or not.

d. Fines, penalties (both criminal cases and based on agreements), punitive damages, and exemplary damages (additional losses, as punishment, are given to the plaintiff outside or above the compensation for losses that should be). 
e. Loss caused by dishonesty, fraud, criminal acts or revenge, or any act/omission that violates local laws or regulations, or other negligence that is not included in the category of medical negligence, any services provided while under the influence of alcohol, drugs, or all services provided based on the agreement on the results (Resultaat Verbintennis) (need to arrange the assessment of the insured and the insured institution works).

f. The medical action given is not for reasons of diagnosis, therapy, medical rehabilitation, prevention, and medical protection (E.g, cosmetic/aesthetic purposes).

g. Genetic manipulation/engineering.

h. Activities related to the processing, storage, and transportation of blood and or blood products in a blood bank.

i. Activities of non-anesthesia doctors with non-local anesthesia or all procedures performed for non-local anesthesia unless the anesthesia is carried out by a valid and authorized anesthesiologist in an accredited and licensed hospital following applicable legal regulations and professional standards.

j. Losses arising from professional services provided by the Insured to the Insured's spouse and/or to direct family members of the Insured and/or people who work for the Insured or are under the Insured's supervision.

k. Any liability arising solely from the status of the Insured party, or his activities in his capacity as an officer, director, partner, holder of a management position by election or appointment, or a shareholder of a partnership or joint venture or other organization including trade unions, charitable or business organizations, or as elected public officials or as employees of a subdivision or agency of government.

1. Claims based on, arising out of, or resulting from a guarantee or warranty on the outcome of medical action.

m. Claims arising out of loss or damage to the patient's belongings that are in the care, custody, or control of the Insured, or damage or misplacement or loss of documents (in any form), whether written, printed, or reproduced in any way or information stored in private electronically or by computer, or material entrusted to or in the care, custody or control of the Insured.

n. Claims by one of the Insured parties against other Insured parties except between the two insured parties in the Doctor and Patient relationship.

o. Claims that directly or indirectly without the knowledge of the insured arising from losses due to the use of tools or drugs that do not function properly or are not suitable for use or due to product defects.

Based on the provisions set out above, this medical professional liability insurance can only cover compensation related to medical negligence caused by the insured. Regarding the part that is the insurance limit, it contains provisions for the insurer to be responsible for the payment of compensation with the highest value of IDR. 500,000 .000 after deducting the amount of risk that is the responsibility of the insured such as all compensation for losses arising from claims in an event; and claims settlement costs in connection therewith.

Likewise, regarding the aggregate limit, the highest amount paid by the insurer is IDR. $500,000,000$ in one insurance period in the form of the total amount of losses arising from claims in each event, and all claims settlement costs in connection with it, since the first claim was filed. During the policy period. If the compensation from the insurer reaches the maximum aggregate limit stated in the Summary of Coverage in Principle 3B, the policy will automatically be declared invalid.

The policy that is the handle for the insurer and the insured sometimes does not resolve the problem between the two parties and it may be that the dispute requires resolution. If a 
dispute arises between the Insurer and the Insured as a result of the intepretation of the responsibility or the amount of compensation from this Policy, then the dispute will be resolved through reconciliation or deliberation within a maximum period of 60 (sixty) calendar days from the onset of the dispute. The dispute has arisen since the Insured stated in writing his disagreement on the matter in dispute. If the dispute resolution through peace or deliberation cannot be reached, the Insured may request the Indonesian Insurance Mediation Board (BMAI) to act as a mediator in an effort to reach a settlement of the dispute in accordance with the terms and conditions stipulated applies to BMAI.

\subsection{The process of filing a claim for medical professional liability insurance LC. BUMIDA}

In the event of a medical dispute or potential medical dispute, the doctor as the insured must immediately notify the insurer verbally, which is then follow up with a written report regarding all events that may result in a claim.

The notification includes:

a. Background and chronology of events;

b. Potential injuries and the names and addresses of people involved in the incident, including potential claimants;

c. How did the Insured become aware of the incident?

d. Why the Insured party expects that there will be a claim thereof.

Only after the insured makes his insurance claim can the compensation be paid by the insurer. The flow of the medical professional liability insurance claim process at LC. BUMIDA is as follows:

1. The doctor's claims to the insurer will be accepted by the staff.

2. After the report is received, a policy verification will be implemented to ensure whether the claim is following the terms of coverage or not. Where the inspection process includes the validity of the policy (insurable interest, insurance period, authenticity, premium paid off), and the risks that occur are guaranteed by the policy. If it is following the provisions then the policy is valid and the process will be continued at the next stage. But, if it is not following the provisions of the policy it will cause the policy to be invalid and the technical/general section head will make a rejection letter signed by the head of the operational office to be submitted to the policyholder or insured.

3. A temporary loss report (LKS) is prepared by the technical/general section head which contains the maximum estimated loss to be paid by the insurer or the insurer. After that, the LKS will be approved and signed by the Head of Engineering and the Head of the Branch to be sent to the Head of the Branch and the local medico legal team as a report.

4. The Head of Engineering/General will coordinate with the local medico legal team and the stages are in the form of surveys, communication with doctors and patients, and then conducting case analysis. The results of the medico legal analysis are then compiled into a written report called the coordination report with the local medico-legal team.

5. After getting the results of the report, the LKS will be readjusted by the claims/general staff if it turns out that the results of the identification that have been carried out result in a different amount of loss from the LKS that has been made previously, which will then be approved and signed by the head of engineering and the head of the operational office.

6. For the next process, the completeness of the documents is checked by the claims/general staff. If the file is complete then the status is $\mathrm{A} / 2$ while if the file is incomplete then the claims/general staff will confirm to the insured to complete the file. 
7. If the status is $\mathrm{A} / 1$, then underwriting will be carried out for recommendations to the Head Office carried out by the Head of Engineering/General. The documents required are underwriting policies, LKS, supporting documents and evidence, and reports on the results of coordination with the local medico-legal team. The analysis is carried out based on the underwriting policy and makes recommendations on claims to the Head Office which are submitted in a confirmation letter to the central office.

8. Head of engineering/general submits a claim authorization request to the head office to see the SOP for authorization of professional liability insurance claims by submitting a claim authorization permit file to the head office. After receiving the claim authorization from the head office, if it is approved by the operational office through its claims staff, it will make an LKP and answer the company's decision to the insured. Meanwhile, if it is not approved, the head of engineering/general will make a rejection letter with a document called a rejection note. Then will be sent to the marketing department or the insured, and the status is $\mathrm{B} / 2$. For the refusal of the claim that occurred, if the insured submits an appeal, the process can be continued with the settlement of claims Ex-gratia (SOP ex-gratia)

9. If the claim value is still within the limit of the operational office's authority, the claims staff can immediately make an LKP and a claim payment receipt that will then be signed by the general technical section head and the branch head.

10. The claim payment process made by the insurer to the insured is implemented by the finance department, and proof of claim payment is copy to the local medico-legal team.

In realizing the claim submitted by the Insured to the Insurer, which in this case is LC.

BUMIDA, the doctor as the Insured must prepare the following requirements:

a. The doctor must complete the required copy of the claim filing requirements.

b. A copy of the required completeness requirements consists of a photocopy of a doctor's professional insurance policy that is still valid, a photocopy of an Identity Card, a photocopy of a Practice License, and an appropriate Registration Certificate, a chronology of cases made by the doctor concerned, telephone number and active email address as a medium of communication.

c. Claims will be declared valid/eligible to be processed if the requirements are complete and at the time of the incident (claim-made basis) the policy is still valid (still active) or it could be that the time the incident took place was within the tolerance range of 14 days after the policy validity period ended.

d. Considerations for determining claims are seen from the scope of coverage which consists of Insurance Agreements, Payment of Insurance Claims, and Exceptions.

In terms of determining how to calculate the number of claims made by the Medico legal

Team regarding the payment of medical professional insurance claims, the Medico legal Team will take steps and consider:

1. The claim calculation is carried out by the BUMIDA Medicolegal Team by considering various aspects such as the insurance agreement made by the insurer and the insured as long as the insured is still an insurance participant without being terminated, when this insurance is valid, where this insurance can be used, and insurance is only valid in the country of address insured.

2. The cost aspect that has been incurred by the patient (real cost).

3. Aspects Legal costs to be incurred such as revocation, termination of cases, and SP3, legal team assistance costs (lawyers).

4. The value aspect of the patient's demands.

5. Total claim is IDR 500,000,000 
6. Medico legal analysis is carried out based on various considerations, namely by conducting case analysis based on tests, namely the light bulb test, Bolitho test, Montgomery test, and Chester test. The Bolam test or also called substandard care is a test that is carried out by analyzing the practitioner's responsibility. Bolitho test (logical care) is an analytical method with treatment that must have a logical basis, so it can be accepted logically and maintained. Then the Montgomery test (Proper \& adequate information consent) is carried out by digging up adequate information obtained from the operator or the person concerned that cannot be delegated and must be recorded. Finally, the analytical method using the Chester test (causation or but for a test) is a test that is carried out based on estimates, for example, if it were not for the action/therapy then there would be no such loss. After analyzing the various methods, the doctor's legal position as the client of the case will be obtained. With consideration of other aspects, the Medico legal Team will then determine the number of claims that can be paid in the mediation process and or the negotiation process carried out in an agreement.

Furthermore, the Medico legal Team in analyzing to weigh (analyze) whether a doctor made a mistake/omission uses four conditions for determining errors/omissions known as 4D, namely:

1. Duty of care, looking at professional obligations and contractual obligations with patients. To determine professional obligations, it is seen from several criteria, such as competency standards, behavioral standards, and service standards, while obligations due to the doctor-patient relationship are seen from the doctor's actions such as ethical general attitudes and behavior and maximum efforts at least if the actions taken are not successful must provide reasonable reasons to the patient.

2. Dereliction / Breach Of Duty, namely seeing violations of obligations in the form of default or violating the rules/procedures that must be implemented.

3. Damages, namely seeing the losses caused can be in the form of injury, death, or loss

4. Direct causal ship is to see the causal relationship arising from the violation with the losses experienced, for example, if the scissors are not left behind then there will be no perforation-peritonitis if the diagnosis is not wrong or too late then the patient can be helped.

\subsection{Constraints in the claim submission process}

In disseminating the medical professional liability insurance, LC. BUMIDA still encounters several obstacles including:

1. There is no strong awareness from the doctor about the risks of work or services provided to patients, so there is still a strong reluctance/desire to become a participant in the medical professional liability insurance.

2. There is no strong awareness from the Hospital that employs doctors on the risks of work or services provided to patients, so there is still a strong reluctance/desire to oblige every doctor who works at the Hospital to be a participant in the medical professional liability insurance.

3. There is no nationally binding regulation, where the existing regulations are generally still advisory.

4. There is no good awareness and understanding from policymakers, both central and local, to participate in implementing the obligation to take part in the medical professional liability insurance for every practicing doctor.

As for the claim process, there are several obstacles faced, namely as follows: 
1. There is no common understanding of the incident that happened to the patient so that the patient and family often generalize the demands by defining errors/omissions that occur as malpractice. This condition will certainly lead to a wrong perception of medical actions that have been carried out by doctors, which in the end the process of mediation and or negotiations that will be achieved is getting further and further from an agreement. The analysis of the Medico legal Team, in the end, did not match the norms of medico legal analysis.

2. Doctors and/or hospitals sometimes resolve cases on their own without consulting LC. BUMIDA and/or the Medico legal Team. This condition can make the claims filed by the doctor as the insured become constrained.

3. Convoluted patients in agreeing on peace. In this situation, the submission of claims submitted by the insured can be hampered and can even fail and lead to disputes in court without a mediation process and or negotiations that run smoothly.

4. There is no openness from the hospital to provide the patient's medical record file to the medico legal team. If this happens, it will make it difficult for the medico legal team to carry out a medico legal analysis properly, that in the end, the results of the medico legal analysis are difficult to produce and unable to determine the legal position of doctors in dealing with medical disputes that occur.

5. Incomplete information provided by doctors as clients and hospitals for other informal information that is considered important. Under these circumstances, it is difficult for the medico legal team to carry out a perfect medico legal analysis.

6. Doctors experience extreme fear so that they do counter-productive things that hinder the mediation and/or negotiation process, this result in the process leading to reaching an agreement between the parties (doctor and patient) that cannot be fulfilled.

7. The claim submission process does not meet the administrative elements contained in the insurance policy, including events that occur outside the active period of the policy and incomplete other supporting documents.

8. The doctor ignores the analysis from the medico legal team regarding the payment of the claim so that the doctor as the insured does not accept the results of the medico legal team's analysis, which in the end takes steps that result in the claim process failing.

All of the obstacles mentioned above, if they can be avoided by the doctor as the insured, will certainly result in a smooth claim process as expected to resolve medical disputes that occur.

\section{Conclusion}

Whereas referring to the Regulation of the Financial Services Authority Number 23/Pojk.05/2015 concerning Insurance Products and Marketing of Insurance Products, referring to Article 255 of the Commercial Code and Article 19 paragraph (1) of Government Regulation Number 73 of 1992 concerning Insurance Administration, the contents of the agreement in the Policy The Doctor's Professional Insurance issued by the BUMIDA Limited Liability Company has complied with the basic principles of insurance. Similarly, referring to Article 1320 of the Civil Code and Article 255 of the KUHD, the contents of the agreement in the Doctor's Professional Insurance Policy issued by BUMIDA Limited Liability Company have fulfilled the principles and principles of the agreement, namely consensual, that is, 
formed based on an agreement from the parties, as well as the rights and obligations the parties.

That the claim process on the BUMIDA Limited Liability Company medical professional insurance policy in medical dispute resolution has a claim process method and flow starting with the doctor making a claim to the insurer, verifying and validating the claim by staff, issuing and submitting a temporary loss report (LKS) to the policyholder or the insured, survey efforts and mediation/negotiations by the technical/general head in coordination with the medico legal team to conduct a medico legal analysis and then produce a medico legal analysis adapted to the LKS, the document completeness process, the submission of the underwriting process and if approved by the head office, the operational office will make LKP which is then continued with the claim payment process by the finance department with proof of claim payment copied to the local medico legal. If the insured submits an appeal, the process can be continued with the settlement of claims Ex-gratia (SOP ex-gratia).

That the constraints of BUMIDA Limited Liability Company in making claims for medical insurance financing are as follows: First, every incident that happens to a patient is always defined as malpractice, Second, doctors and/or hospitals sometimes resolve cases independently, Third, the patient is complicated in agreeing on peace, Fourth, the hospital does not want to provide the patient's medical record file as analysis material, Fifth, the information provided by the doctor as a client is incomplete, Sixth, the doctor experiences extreme fear so that they do things that are counterproductive, Seventh, the claim submission process does not fulfill administrative elements such as events that occur outside the active period of the policy. Eighth, the doctor forces the Medico legal Team to make claims payments according to the patient's demands and ignores the analysis of the BUMIDA Medico legal Team.

\section{Suggestion}

1. Carry out continuous guidance and counseling efforts to doctors who face problems or demands,

2. Conduct regular socialization to doctors and hospital management regarding the existence and utilization of medical professional insurance,

3. Approaching professional organizations such as the Indonesian Doctors Association and related organizations such as the All-Indonesian Hospital Association, the Association of Doctors' Specialists, and the interest in the importance of the existence of medical professional liability insurance for every doctor in carrying out the medical practice.

4. Approaching and submitting to the government to be able to realize mandatory and binding regulations related to medical professional liability insurance.

5. Conducting scientific studies and or ongoing research in order to strengthen the study of medical professional liability insurance.

\section{References}

[1] Afandi , D. 2009. Mediasi : Alternatif Penyelesaian Sengketa Medis, Maj Kedokt Indon, Volum: 59, Nomor: 5, p, 189

[2] Almatsier, M. 2000. Antisipasi Kesiapan Tenaga Kesehatan Dan Profesi Kedokteran Dalam Rangka Pemberlakuan Uu No.8/1999 Tentang Perlindungan Konsumen (Kontroversi Uupk Dalam Pelayanan Medik) : Makalah Ketua Umum Pd Idi, Simposium; Problema Dan Solusi Praktek Dokter, Padang, p, 2.

[3] Amrin, A. 2006. Asuransi Syariah Keberadaan dan Kelebihannya diTengah Asuransi Konvesional, PT Elex media komputindo, Jakarta, p, 121 
[4] BUMIDA. 2018. Profil Perusahaan, Magazine, p, 3 and 6

[5] Departemen Pendidikan Nasional. 2005. Kamus Besar Bahasa Indonesia, Departemen Pendidikan Nasional, Jakarta, p, 897

[6] Gunawan. 1991. Memahami Etika Kedokteran, Kanisius, Yogyakarta, p, 19.

[7] Hadjon, P.M. 1994. Pengkajian Ilmu Dogmatik (Normatif), Fakultas Hukum Universitas Airlangga, Surabaya, p, 2

[8] Hartono, S.R. 1985. Asuransi Dan Hukum Asuransi Di Indonesia, Semarang Press: Ikip, Semarang, p, 6-7

[9] Heriani, I. 2019. Perlindungan Hukum Atas Hak Pasien Dari Penyelesaian Sengketa Medik Antara Pasien Dengan Dokter Dan/Atau Tenaga Medis Serta Rumah Sakit, Al - Ulum Ilmu Sosial Dan Humaniora, Volume 5 Nomor 2, p, 2

[10] Https://Id.Wikipedia.Org/Wiki/Asuransi_Umum_Bumiputeramuda_1967, Accessed on22 December 2020, 12.09

[11] Https://Kebijakankesehatanindonesia.Net/25-Berita/Berita/167-Ketua-Mkdki-Kami-Tak-MengenalIstilah-Malpraktek, Accessed on 23 Desember 2020, 14.27

[12] Interview with John Sirait, AAAIK, QIP, CRMO, Kepala Cabang Perseroan Terbatas Bumi Putera Muda, data diolah pada 29 Desember 2020 pada pukul $21.40 \mathrm{wib}$

[13] Jauhari, M. F. 2019. Urgensi Asuransi Profesi Dalam Perkembangan Bisnis Di Indonesia, Fairness And Justice: Jurnal Ilmiah Ilmu Hukum, p, 60, 17(1)

[14] Kolopaking, A.D.A. 2013. Asas Itikad Baik Dalam Penyelesaian Sengketa Kontrak Melalui Arbitrase, Alumni, Bandung, p, 8

[15] Komalawati, V. 1989. Hukum Dan Etika Dalam Praktek Dokter, Pustaka Harapan, Jakarta, p, 30 Kitab Undang-Undang Hukum Dagang

[16] Mariyanti, N. 1988. Malapraktek Kedokteran Dari Segi Hukum Pidana Dan Perdata, P.T. Bina Aksara, Jakarta, 1988, p.1. see too Machmud, S. 2008. Penegakan Hukum Dan Perlindungan Hukum Bagi Dokter Yang Diduga Melakukan Medikal Malpraktek, Mandar Maju Bandung, p

[17] Mulyadi, D. 2020. Alternatif Penyelesaian Sengketa Kelalaian Medik Yang Berkeadilan Di Indonesia, Logika : Journal Of Multidisciplinary Studies, Vol. 11 Nomor 02 Desember, p, 126

[18] Muthohari, N. 2012. Panduan Membeli dan Menjual Asuransi, Buku Pintar, Yogyakarta, p, 14

[19] Rastuti, T. 2011. Aspek Hukum Perjanjian Asuransi, Pustaka Yustisia, Yogyakarta, p, 253

[20] Sastrawidjaja, M.S. 1997. Aspek-Aspek Hukum Asuransi Dan Surat Berharga, Alumni, Bandung, $\mathrm{p}, 43$

[21] Soekanto,S. 1986. Pengantar Penelitian Hukum, Ui Pres, Jakarta, p,125

[22] RI Law No: 29 of 2004, Regarding Medical Practice, Article 29 Paragraphs (1) and (3)

[23] Law of the Republic of Indonesia Number 30 of 1999 concerning Arbitration and Alternative Dispute Resolution

[24] The 1945 Constitution of the Republic of Indonesia Article 28h Paragraph (1) and Article 34 Paragraph (2)

[25] Wasisto B, Suganda S. 2004. Perilaku Profesional Sebagai Kontinum Etis, Disiplin Dan Hukum Dalam Mencegah Masyarakat Gemar Menggugat (Litigious Society), Proceeding Pertemuan NasionalIv Jaringan Bioetika Dan Humaniora Kesehatan Indonesia (Jbhki), Jakarta, Fakultas Kedokteran Universitas Indonesia, 